\title{
青年期男女の健康観と食生活に関する研究
}

\author{
大野佳美 $* 1 \cdot$ 大坪芳江 ${ }^{* 1} \cdot$ 井澤美佐代 $* 1 \cdot$ 押谷奈緒子 $* 1 \cdot$ 岸本麻紀 $* 1 \cdot$ 長田久美子 $* 2$ \\ 田村俊秀 $* 2$. 石津日出子 $* 3$ ・笠井八重子 $* 4$ \\ $\left(* 1\right.$ 武庫川女子大学生活環境学部, ${ }^{* 2}$ 兵庫医科大学, ${ }^{* 3}$ (元) 近畿大学農学部, ${ }^{* 4}$ 岡山大学教育学部)
}

\section{Studies on Consciousness of Health and Dietary Style among Young Adults}

\author{
Yoshimi Ohno*1, Yoshie Ohtsubo*1, Misayo Izawa*1, Naoko Oshitani*1, Maki Kishimoto*1, \\ Kumiko Nagata*2, Toshihide Tamura*2, Hideko Ishizu*3, Yaeko Kasai*4 \\ ${ }^{* 1} M u k o g a w a$ Women's University, 6-46, Ikebiraki-cho, Nishinomiya-shi, Hyogo, 663-8558 \\ ${ }^{* 2}$ Hyogo College of Medicine, 1-1, Mukogawa-cho, Nishinomiya-shi, Hyogo, 663-8131 \\ ${ }^{*}$ Kinki University (retd.), 3327-204, Naka-machi, Nara-shi, 631-0052 \\ ${ }^{* 4}$ Okayama University, 3-1-1, Tsushimanaka, Okayama-shi, 700-8530

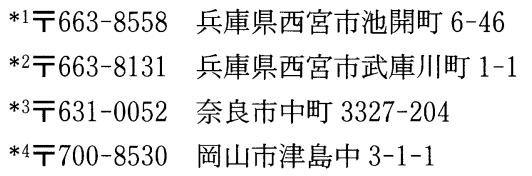

Studies on the consciousness of health and dietary style were conducted among 329 male and 406 female students living in Kinki and Okayama areas.

Many students were interested in maintaining good health, but male students were more interested in "amusement or pleasure" and "love", while females "fashion" and "amusement or pleasure". Most students considered that the most important factor for good health was "sleeping time" or "good balanced nutrient", not "exercise".

Foods which students tried to eat were milk and dairy products and vegetables. Male student preferred mostly "western-style a table d'hôte", while females, "a la carte" when they ate out.

Students who were more interested in their health paid more attention to balanced diets, tried to obtain more information concerning health and nutrition and scored higher on the evaluation of their dietary style. Students who scored lower on the evaluation of their dietary style ate more out and sweets.

\section{1. 緒言}

近年, 日本の生活様式の多様化に伴って食生活が变化 し，各々が好きなものを好きな時に食べる傾向がみられ る. 一方，運動不足によるエネルギー消費の低下，グル メ志向等によるエネルギーや栄養素の摄取過多, ダイエ
ット志向による極端な食事制限等によってさまざまな健 康上の問題が生じている.このような食生活の乱れが生 活習慣病の原因となる可能性が高く, 偏った食生活は若 者ほど多いといわれている1),2)。すなわち，適切なエネ ルギーや栄養素の摂取が健康と食生活の向上に不可欠で あり，そのためには青年期における食生活のあり方が重 
要である.

そこで,生活習慣病予防に役立てることを目的として， 青年期にある男女の健康に対する興味・関心，その情報 源や健康食品および市販菓子, 外食頻度など食生活に関 する調査を実施し，それらの関連性について比較検討し た.

\section{2. 方 法}

兵庫, 奈良, 岡山の 3 地域の大学に通う19２4歳の大 学生（男子329名, 女子406名）を対象とし, 2000年 7 月 〜2001年 4 月に質問紙調查法を用い, その場で記入, 回 収する方法でアンケート調査を実施した.

調査内容は健康と食生活に対する意識, 健康食品の利 用状況，外食および市販菓子の拱取頻度等であった。

集計結果の解析にはアンケート調查集計ソフト「秀吉 for Windows」（SRI 社会情報サービス）によって行っ た. クロス集計の有意差検定は $\chi^{2}$ 検定を使用した.

\section{3. 結果および考察}

大学にお打る所属学部・学科別調査対象者の構成を表 1 に示した. 調査対象者は 1 および 2 年次の学生で, 男

\begin{tabular}{crr} 
表 1 & \multicolumn{4}{l}{ 所属学部·学科別調査対象者の構成(人) } \\
\cline { 2 - 3 } 所属学部 (学科) & 男子 & \multicolumn{1}{c}{ 女子 } \\
\hline 教育·文·法·経済 & 202 & 96 \\
医·薬·歯 & 63 & 40 \\
理·農 & 64 & 36 \\
生活環境 $($ 食物 $)$ & 0 & 234 \\
\hline 合計 & 329 & 406 \\
\hline
\end{tabular}
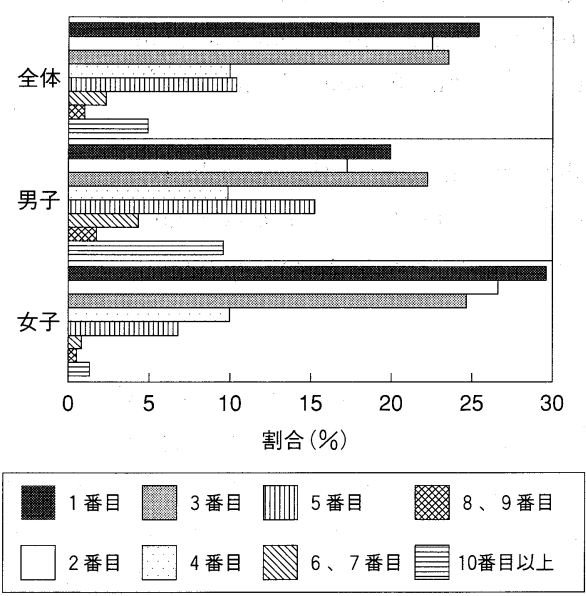

図 1 健康は何番目に大切か
子では教育学部を含む文系が約 $61 \%$, 女子では食物系が 約 $58 \%$ であった。調查対象者の約 $87 \%$ は両親と生活して おり，主な調理担当者は「母」が約 $75 \%$ ，本人が約 $19 \%$ であった。

集計結果には所属学部・学科㧍よび地域別相違が認め られなかったので, 男女別に比較検討した.

\section{（1）健康に対する意識}

図1に示すように,「健康は何番目に大切か」では, $1 \sim 3$ 番目と回答した者は男子の約 $60 \%$, 女子の約 $80 \%$ で, 女子の方が健康の大切さを認識している割合が男子 より多かった．表 2 に示したように健康に関する調查の 結果, 男子の約 $68 \%$, 女子の約 $85 \%$ が健康に興味・関心 が「ある」または「少しある」と答え, 女子の方が多く,

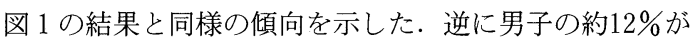
健康に興味・関心が「あまりない」または「ない」と回 答し, 同女子の $1.2 \%$ より多く, 健康への興味・関心 の有無に男女差が認められた. 女子学生を対象に1997年 に実施した調査では, 健康に興味・関心が「ある」「少 しある」の合計が約 $82 \%$ あ゙り, 今回の女子の結果とほ ぼ一致しだ).

表 2 健康に関する調査結果（\%)

\begin{tabular}{|c|c|c|c|c|}
\hline 調査項目 & 全体 & 男子 & 女子 & $\chi^{2}$ 検定 \\
\hline \multicolumn{5}{|c|}{ 健康に興味·関心があるか } \\
\hline ある & 44.2 & 33.7 & 52.6 & \multirow{5}{*}{$p<0.01$} \\
\hline 少しある & 33.1 & 34.4 & 32.1 & \\
\hline ふつう & 16.8 & 20.2 & 14.1 & \\
\hline あまりない & 4.5 & 8.6 & 1.2 & \\
\hline ない & 1.4 & 3.1 & 0.0 & \\
\hline \multicolumn{4}{|c|}{ 健康·栄養に関する知識の情報源 } & \multirow{9}{*}{$\mathrm{p}<0.01$} \\
\hline 家族 & 14.2 & 16.8 & 12.2 & \\
\hline 友人 & 1.8 & 1.9 & 1.7 & \\
\hline 学校 & 21.8 & 15.2 & 26.9 & \\
\hline 医療機関·保健所 & 0.9 & 1.9 & 0.2 & \\
\hline 雑誌·新聞 & 12.7 & 10.6 & 14.0 & \\
\hline テレビ・ラジオ & 40.2 & 39.4 & 41.0 & \\
\hline その他* & 1.9 & 2.5 & 1.5 & \\
\hline 特になし & 6.5 & 11.6 & 2.5 & \\
\hline \multicolumn{4}{|c|}{ 健康のために心がけて摂取している食品群** } & \multirow{11}{*}{$p<0.01$} \\
\hline 魚介類 & 22.8 & 25.4 & 20.5 & \\
\hline 乳類·乳製品 & 59.4 & 50.8 & 66.4 & \\
\hline 大豆·大豆製品 & 18.7 & 12.7 & 23.2 & \\
\hline 緑黄色野菜 & 38.7 & 27.9 & 47.2 & \\
\hline 淡色野菜 & 38.5 & 40.2 & 37.3 & \\
\hline 果実類 & 32.6 & 32.2 & 33.1 & \\
\hline 海藻類 & 18.0 & 14.9 & 20.5 & \\
\hline きのこ類 & 10.0 & 6.2 & 13.1 & \\
\hline その他の食品群 & 3.0 & 3.7 & 2.5 & \\
\hline 特になし & 12.1 & 19.8 & 5.9 & \\
\hline
\end{tabular}

*料理学校.講習会を含む **複数回答 
健康·栄養に関する知識の情報源は男女とも「テレビ, ラジオ」がもっとも多く（男子；約 $39 \%$, 女子 ; 約 $41 \%$ ), つぎに男子では「家族」「学校」「特になし」「雑誌・新 聞」, 女子では「学校」「雑誌・新聞」「家族」であり, 情報源の項目間の割合に有意な男女差があった。平成 6 年国民栄養調査によると, 食に関する知識は $20 \sim 29$ 歳男 女では「テレビ・ラジオ」「家族」がもっとも多く, つ いで「雑誌・本」であり4), 平成 12 年度では男女とも 「テレビ・ラジオ」がもっとも多く，つぎに男子では 「家族」, 女子では「雑誌・本」5)で, これら情報源の項 目は今回の結果と同様であった.

健康のために心がけて摂取している食品群は男女とも 多かったのは「乳類・乳製品」（男子; 約 $51 \%$, 女子; 約 $66 \%), 「$ 緑黄色野菜」扰よび「淡色野菜」の野菜類 （男子；約 $68 \%$ ，女子 ; 約 $85 \%$ ), 「果実類」（男子 ; 約 32 $\%$ ，女子；約 $33 \%$ ）であった. 女子では「乳類・乳製品」 「緑黄色野菜」の回答が男子より多かった。 また, 男子

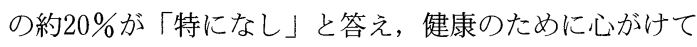
摂取している食品群に男女差があった. 男女とも「乳類 · 乳製品」「野菜類」が多かったことから，「骨粗しょう症」 とカルシウム ${ }^{6), 7)}$, 「便秘解消」や「大腸ガン予防」「美
容」と食物繊維8) 10) など健康と食べものとの関連に関 心を持っていると思われた. これらは最近, テレビや雑 誌などで取り上げられることが多い内容であり，そのた めに知識として得ていると思われる.

図 2 に「健康」と,「遊び」「美容・ファッション」 「学業」「恋愛」をそれぞれに, 興味・関心の強さの割合 （例; 健康+遊び=100）について比較した結果を示した. 男子の約 $69 \%$ が「遊び」を，約 $58 \%$ が「恋愛」の割合を $60 \%$ 以上と答えた. 一方, 女子の約 $53 \%$ が美容・ファ ッション」を, 約 $46 \%$ が「遊び」の割合を $60 \%$ 以上と答 え,「健康」よりもこれらの項目の方が関心・興味が高 かった，逆に，男子の約 $48 \%$, 女子の約 $55 \%$ が学業」 と「健康」をほぼ同程度の割合と答えた。

表 3 に示すように「健康」と，「食事」「睡眠」「運動」 「休養」との関連において, 男子の約 $30 \%$, 女子の約 29 \%が「睡眠」を健康のために重視していると答え, つぎ に「食事」であり，「運動」がもっとも少なかったが， これらの項目間に男女差はなかった。 また，男女とも50 \%以上が食事では「栄養バランス」, 睡眠では「睡眠時 間」に気をつけていると回答した．運動では男子の約 40

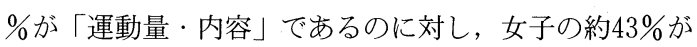
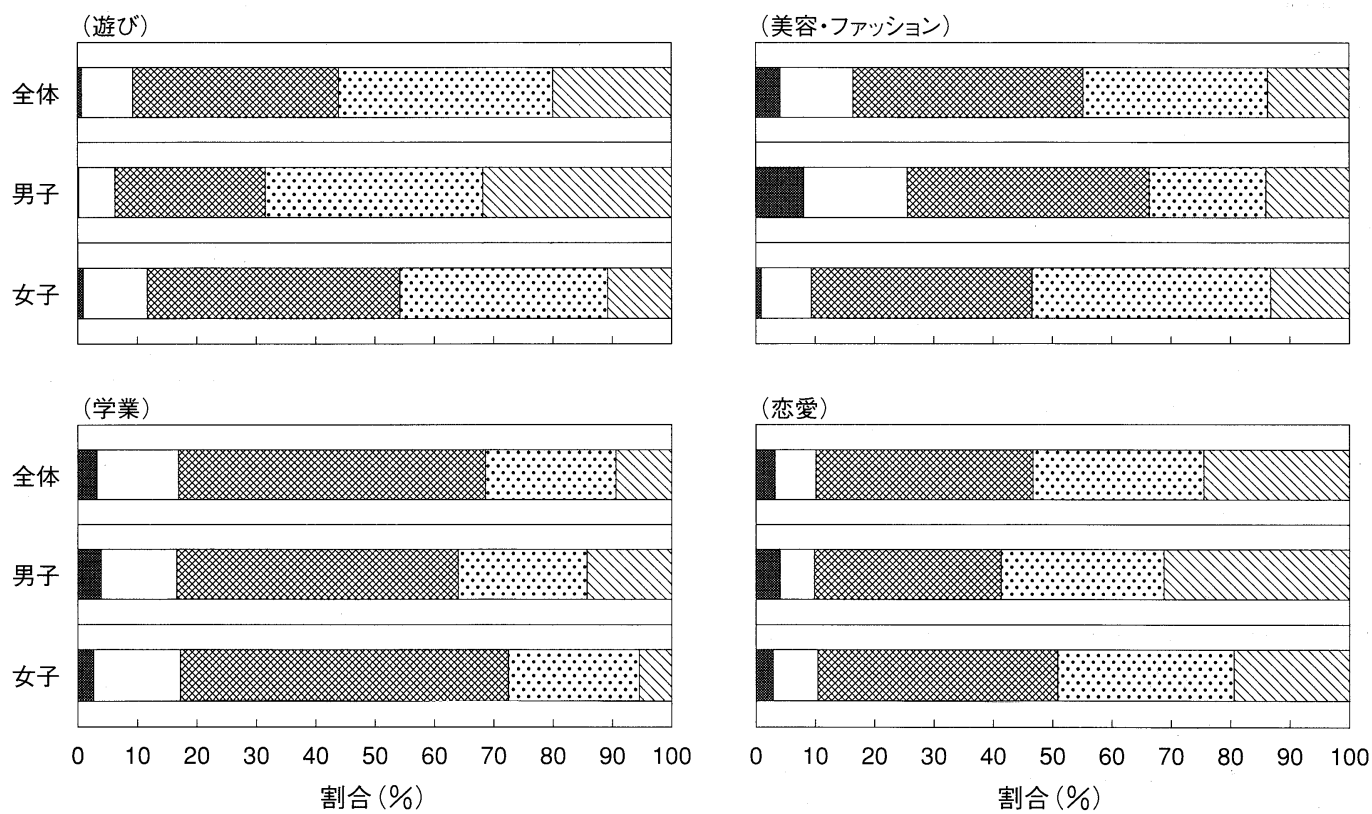

$0-16 \% \square 20-39 \%$ 40-59\% 60-79\% N $60-100 \%$

図 2 健康と「遊び「「美容·ファッション」「学業」および「恋愛」間の興味·関心の強さの割合 
表 3 健康と食事·睡眠·運動·休養との関連（\%)

\begin{tabular}{|c|c|c|c|c|}
\hline 調査項目 & 全体 & 男子 & 女子 & $\chi^{2 \text { 検定 }}$ \\
\hline \multicolumn{4}{|c|}{ 健康のために重視していること } & \multirow{5}{*}{ ns } \\
\hline 食事 & 27.2 & 25.4 & 28.6 & \\
\hline 睡眠 & 29.5 & 29.9 & 29.2 & \\
\hline 運動 & 19.7 & 20.3 & 19.2 & \\
\hline 休養 & 23.6 & 24.4 & 23.0 & \\
\hline \multicolumn{4}{|l|}{ 食事で気をつけていること } & \multirow{6}{*}{$\mathrm{ns}$} \\
\hline 食事量 & 26.1 & 26.6 & 25.7 & \\
\hline 食事回数 & 9.5 & 10.0 & 9.2 & \\
\hline 栄養バランス & 54.3 & 50.9 & 56.9 & \\
\hline 摂取食品数 & 3.3 & 3.4 & 3.2 & \\
\hline その他 & 6.8 & 9.1 & 5.0 & \\
\hline \multicolumn{4}{|l|}{ 睡眠で気をつけていること } & \multirow{6}{*}{$\mathrm{p}<0.01$} \\
\hline 睡眠時間 & 60.5 & 58.7 & 61.8 & \\
\hline 睡眠の深さ & 23.2 & 26.2 & 20.8 & \\
\hline 就寝時間 & 8.5 & 5.6 & 10.9 & \\
\hline 起床時間 & 4.4 & 4.3 & 4.5 & \\
\hline その他 & 3.4 & 5.2 & 2.0 & \\
\hline \multicolumn{4}{|l|}{ 運動で気をつけていること } & \multirow{6}{*}{$\mathrm{p}<0.01$} \\
\hline 運動量·内容 & 33.3 & 39.7 & 28.3 & \\
\hline 1 回あたりの運動量 & 2.9 & 3.1 & 2.7 & \\
\hline 運動頻度 & 24.6 & 25.2 & 23.9 & \\
\hline 特に運動をしていない & 36.6 & 28.6 & 43.1 & \\
\hline その他 & 2.6 & 3.4 & 2.0 & \\
\hline
\end{tabular}

「特に運動をしていない」と答えた。これは, 国民栄養 調査（平成 8 年）の「運動習慣者がもっとも少ないのは 20歳代の女性」との報告11)が「特に運動していない」と の回答を示唆していると思われた. 平成12年度国民栄養 調查結果5)によると，自分の健康づくりのために栄養や 食事を「よく考える」「時々考える」は20～29歳男子で は約 $55 \%$, 同女子では約 $76 \%$ であり，年代が低くなるほ ぞ「あまり考えない」「全く考えない」の割合が増加す ると報告している. 第 6 次日本人の栄養所要量では, 日 常の生活活動を変えるか運動を付加してより健康で充実 した食生活を推奖している12).これらのことから，不規 則な生活や偏った食生活をしていたとしても，明らかな 病的症状の出現が少ないために健康よりも「遊び」「美 容・ファッション」に興味・関心をもっている若者が多 いと推測された。人生 80 年といわれる現在, 健や加に活 動して生きるためには若年時からの生活のあり方が重要 であると考えられる，その一つとして運動の必要性を認 識し, 日常の生活に積極的に取り入れ，運動習慣を身に つけることが必要であると考えられた。

表 4 に示した健康食品の利用状況では, 男子の約 $55 \%$, 女子の約 $65 \%$ 徒りない栄養を補う」,「手軽なバラン ス食品」または「なんとなく」と答えた。一方，男子の
表 4 健康食品の利用状況（\%）

\begin{tabular}{|c|c|c|c|c|}
\hline 調査項目 & 全体 & 男子 & 女子 & $\chi^{2}$ 検定 \\
\hline \multicolumn{5}{|l|}{ 健康食品の利用 } \\
\hline 足りない栄養を補う & 24.1 & 21.2 & 26.6 & \\
\hline 家族·友人に勧められて & 1.1 & 0.6 & 1.5 & \\
\hline 手軽なバランス食品 & 18.8 & 17.8 & 19.6 & \\
\hline メディアからの情報 & 3.4 & 3.1 & 3.7 & ns \\
\hline なんとなく & 13.8 & 16.2 & 11.9 & \\
\hline その他 & 7.4 & 8.4 & 6.5 & \\
\hline 利用しない & 31.4 & 32.7 & 30.2 & \\
\hline \multicolumn{5}{|l|}{ ドリンクタイプの利用頻度 } \\
\hline ほぼ毎日 & 1.5 & 2.5 & 0.7 & \\
\hline 週 $3 \sim 5$ 日 & 1.5 & 2.5 & 0.7 & \\
\hline 週 $1 \sim 2$ 日 & 5.8 & 8.0 & 4.0 & $p<0.01$ \\
\hline 月 $1 \sim 2$ 回 & 16.4 & 22.3 & 11.7 & \\
\hline 年に数回 & 24.8 & 28.5 & 21.6 & \\
\hline ほぼなし & 50.0 & 36.2 & 61.3 & \\
\hline \multicolumn{5}{|l|}{ 錠剂タイプの利用頻度 } \\
\hline ほぼ毎日 & 8.4 & 4.3 & 11.7 & \\
\hline 週 $3 \sim 5$ 日 & 4.3 & 1.6 & 6.5 & \\
\hline 週 $1 \sim 2$ 日 & 5.1 & 4.3 & 5.7 & $p<0.01$ \\
\hline 月 $1 \sim 2$ 回 & 6.6 & 5.6 & 7.4 & \\
\hline 年に数回 & 12.7 & 10.9 & 13.9 & \\
\hline ほぼなし & 62.9 & 73.3 & 54.8 & \\
\hline \multicolumn{5}{|c|}{ 栄養添加ドリンクの利用頻度 } \\
\hline ほぼ毎日 & 3.0 & 3.4 & 2.7 & \\
\hline 週 $3 \sim 5$ 日 & 6.6 & 8.0 & 5.5 & \\
\hline 週 $1 \sim 2$ 日 & 15.6 & 18.3 & 13.4 & ns \\
\hline 月 $1 \sim 2$ 回 & 24.1 & 23.8 & 24.4 & \\
\hline 年に数回 & 21.2 & 18.9 & 22.9 & \\
\hline ほぼなし & 29.5 & 27.6 & 31.1 & \\
\hline \multicolumn{5}{|c|}{ 栄養バランス食品の利用頻度 } \\
\hline ほぼ毎日 & 0.8 & 1.6 & 0.2 & \\
\hline 週 $3 \sim 5$ 日 & 1.7 & 1.9 & 1.5 & \\
\hline 週 $1 \sim 2$ 日 & 7.4 & 6.8 & 7.9 & $p<0.05$ \\
\hline 月 $1 \sim 2$ 回 & 22.2 & 26.7 & 18.6 & \\
\hline 年に数回 & 31.0 & 29.5 & 32.0 & \\
\hline ほぼなし & 36.9 & 33.5 & 39.8 & \\
\hline
\end{tabular}

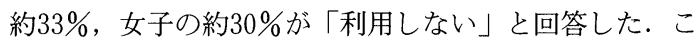
の結果は国民性の違いによるものであるかもしれない が, アメリカ人学生の約 $66 \%$ が健康食品を「推取しな い」13) との回答よりも少なかった。健康食品では女子の 約 $12 \%$ が錠剂タイプを「ほぼ毎日」と回答したが，対象 者の多くはこれら健康食品の利用頻度は栄養添加ドリン クの男子の約 $19 \%$ ，女子の約13\%に抢いて週 1２ 日以 外は月 $1 \sim 2$ 回以下で, 男女とも「足りない栄盖を補う」 ために健康食品を利用すると回答したが，実際にはその 利用頻度は低かった．ビタミン剂やカルシウム剤などの 栄養補助食品の購入は少なく, また，それらを理解して 購入しているかどうか疑問であるとの報告 ${ }^{14)}$ がある。こ 
れらを考え合わせると, 健康よりも他に興味・関心があ ると回答したのと同様に健康食品を積極的に利用する必 要性を感じていないと思われた。

\section{（2）外食状況と市販菓子の摂取頻度}

表 5 に外食状況と市販菓子の摂取頻度を示した. 外食 頻度は全体の約 $30 \%$ が「ほぼ毎日」と答え，ほとんどの 男女が少なくとも週 1 ～ 2 日以上の外食をしていた. 外 食は男子の約 $41 \%$,女子の約 $56 \%$ が昼食, 男子の約 $51 \%$, 女子の約 $36 \%$ が夕食と答え, 朝食は男女とも極めて少な かった，外食でよく食べるメニューは男女とも洋食が多 く, 男子では「洋食定食」を選び，女子では「洋食一品 料理」を選択すると答えた。洋食, 和食, 中華いずれに おいても, 男子の方が女子よりも定食を選んでいる割合 が多く, 男女によって選択する料理が有意に異なった。

表 5 外食状況と市販菓子の摂取頻度（\%)

\begin{tabular}{|c|c|c|c|c|}
\hline 調査項目 & 全体 & 男子 & 女子 & $\chi^{2}$ 検定 \\
\hline \multicolumn{5}{|l|}{ 外食頻度 } \\
\hline ほぼ毎日 & 29.2 & 35.7 & 24.0 & \multirow{6}{*}{$p<0.01$} \\
\hline 週 $3 \sim 5$ 日 & 31.4 & 30.7 & 32.3 & \\
\hline 週 $1 \sim 2$ 日 & 27.2 & 23.0 & 30.4 & \\
\hline 月 $1 \sim 2$ 回 & 9.4 & 5.9 & 12.1 & \\
\hline 年に数回 & 1.8 & 3.1 & 0.7 & \\
\hline ほぼなし & 1.0 & 1.6 & 0.5 & \\
\hline \multicolumn{5}{|l|}{ いつ外食するか } \\
\hline 朝食 & 2.2 & 1.3 & 3.0 & \multirow{5}{*}{$p<0.01$} \\
\hline 昼食 & 49.6 & 40.6 & 56.3 & \\
\hline 夕食 & 42.3 & 51.3 & 35.5 & \\
\hline 間食 & 3.1 & 2.9 & 3.2 & \\
\hline その他 & 2.8 & 3.9 & 2.0 & \\
\hline \multicolumn{4}{|c|}{ 外食でよく食べるメニュー } & \multirow{9}{*}{$p<0.01$} \\
\hline 洋食一品料理 & 28.4 & 10.2 & 42.5 & \\
\hline 洋食定食 & 26.8 & 39.0 & 17.3 & \\
\hline 和食麺類 & 9.6 & 8.3 & 10.8 & \\
\hline 和食どんぶり類 & 6.7 & 7.6 & 6.0 & \\
\hline 和食定食 & 13.1 & 16.8 & 10.0 & \\
\hline 中華一品料理 & 5.9 & 9.8 & 2.8 & \\
\hline 中華定食 & 2.7 & 5.1 & 0.8 & \\
\hline ファーストフード & 6.8 & 3.2 & 9.8 & \\
\hline \multicolumn{4}{|c|}{ 外食で重視していること } & \multirow{5}{*}{$p<0.05$} \\
\hline 価格 & 31.9 & 34.8 & 29.6 & \\
\hline その時の気分 & 32.0 & 32.3 & 31.7 & \\
\hline 栄養バランス & 18.2 & 17.7 & 18.5 & \\
\hline カロリー & 18.0 & 15.2 & 20.2 & \\
\hline \multicolumn{4}{|l|}{ 市販菓子の摂取頻度 } & \multirow{7}{*}{$p<0.01$} \\
\hline ほぼ毎日 & 20.0 & 11.9 & 26.6 & \\
\hline 週 $3 \sim 5$ 日 & 23.5 & 15.9 & 29.5 & \\
\hline 週 $1 \sim 2$ 日 & 34.5 & 39.4 & 30.8 & \\
\hline 月 $1 \sim 2$ 回 & 15.9 & 22.5 & 10.4 & \\
\hline 年に数回 & 2.8 & 4.4 & 1.5 & \\
\hline ほぼなし & 3.3 & 5.9 & 1.2 & \\
\hline
\end{tabular}

外食の選択時に，男女いずれも「価格」「その時の気分」 を重視する割合が高く，その他に女子では「カロリー」 を重視していた。「栄養バランス」を考慮するならば一 品料理よりも定食を選択する方がよいと思われるが，表 3 の健康に関する食事では「栄養バランス」に気をつけ ていると回答した者が多かったにもかかわらず, 若者で は「価格」「その時の気分」が優先するようであった． これは女子大生では外食で嘫好や価格に気をつけてお り, 栄養への関心が低いとの報告 ${ }^{15)}$ と同様の結果であっ た。

市販菓子の摂取頻度は男子では「週 $1 \sim 2$ 日」がもっ とも多く, つぎに「月 $1 \sim 2$ 回」と答えたが, 女子では 「ほぼ毎日」が約 $27 \%$,「週 3〜 5 日」「週 1〜2 日」が それぞれ約 $30 \%$, 約 $31 \%$ で, 摂取頻度は男子よりも高く, 男女差があった。

\section{（3）健康への興味・関心とその他の項目との関連性}

表 6 に健康に興味・関心と健康・栄養に関する知識の 情報源, 健康のために心がけて摄取している食品群抢よ び食生活の自己評価（100点満点）との関連性を示した. 男女とも健康に興味・関心がある者ほど, 健康・栄養に 関する情報源が多く積極的に情報を得ており，「特にな し」と答えた割合が少なかった．また，健康に興味・関 心のある者ほど心がけて摂取している食品群の種類が多 かった。「心がけて摂取している食品群が特になし」と 回答した者は健康・栄養に関する知識の情報源や食べも のについての興味・関心が少ないためではないかと推測 される.「健康に興味・関心」と食生活の自己評価との 関連性は男子では自己評価の高い者ほど健康に興味・関 心が「ある」と答えた割合が多かった，女子では「ない」 と答えた者はなく, 健康への興味・関心の程度にかかわ らず,男子よりも全体に自己評価が高い割合が多かった。

図 3 に食生活の自己評価点の平均值と外食抢よび市販 菓子の摂取頻度との関連性を示した. 外食の摂取頻度が 「ほほ毎日」では, 男女とも食生活の自己評価点の平均 值が約 37 点で, また, 外食の摂取頻度が低いほど, 食生 活の自己評価点の平均値が高くなる傾向を示した. 市販 菓子の摂取頻度を「ほぼなし」と回答した者, 特に女子 では食生活の自己評価点の平均值が 65 点と高かった。

食生活を充実させるために必要な項目を「食に関する 知識」「経済力」, 調理・買いものなどの「時間」, 食生 活を充実させるという「強い意志」から選んでもらった ところ，図 4 に示すように男女とも約 $25 \%$ が「食に関す る知識」で, 他に男子では「強い意志」「経済力」, 女子 では「強い意志」と回答した割合が多かった，平成11年 
表 6 健康に興味·関心との関連性（\%)

\begin{tabular}{|c|c|c|c|c|c|c|c|c|c|c|c|c|c|c|}
\hline \multirow[b]{2}{*}{ 調査項目 } & \multicolumn{6}{|c|}{ 男子（健康に興味·関心） } & \multirow[b]{2}{*}{$\chi^{2 \text { 検定 }}$} & \multicolumn{6}{|c|}{ 女子(健康に興味·関心) } & \multirow[b]{2}{*}{$\chi^{2}$ 検定 } \\
\hline & 全体 & ある & 少しある & ふつう & あまりない & ない & & 全体 & ある & 少しある & ふつう & あまりない & ない & \\
\hline \multicolumn{15}{|c|}{ 健康·栄養に関する知識の情報源 } \\
\hline 家族 & 16.9 & 14.2 & 12.6 & 24.6 & 25.0 & 20.0 & \multirow{8}{*}{$\mathrm{p}<0.01$} & 12.2 & 10.5 & 14.7 & 10.7 & 40.0 & 0.0 & \multirow{8}{*}{$\mathrm{p}<0.01$} \\
\hline 友人 & 1.9 & 1.9 & 2.9 & 1.6 & 0.0 & 0.0 & & 1.8 & 1.0 & 2.3 & 3.6 & 0.0 & 0.0 & \\
\hline 学校 & 14.9 & 14.2 & 18.4 & 16.4 & 3.6 & 10.0 & & 27.0 & 29.0 & 28.7 & 17.9 & 0.0 & 0.0 & \\
\hline 医療機関·保健所 & 1.9 & 0.9 & 1.0 & 1.6 & 3.6 & 20.0 & & 0.2 & 0.0 & 0.0 & 0.0 & 20.0 & 0.0 & \\
\hline 雑誌·新聞 & 10.7 & 17.9 & 9.7 & 3.3 & 7.1 & 7.1 & & 14.0 & 15.2 & 14.0 & 10.7 & 0.0 & 0.0 & \\
\hline テレビ・ラジオ & 39.6 & 35.8 & 49.5 & 32.8 & 32.1 & 40.0 & & 40.8 & 41.0 & 38.8 & 46.4 & 20.0 & 0.0 & \\
\hline その他* & 2.6 & 6.6 & 1.0 & 0.0 & 0.0 & 0.0 & & 1.5 & 1.9 & 0.8 & 1.8 & 0.0 & 0.0 & \\
\hline 特になし & 11.4 & 8.5 & 4.9 & 19.7 & 28.6 & 10.0 & & 2.5 & 1.4 & 0.8 & 8.9 & 20.0 & 0.0 & \\
\hline \multicolumn{14}{|c|}{ 健康のために心がけて摂取している食品群 } & \multirow{11}{*}{ ns } \\
\hline 魚介類 & 10.9 & 10.9 & 11.9 & 10.0 & 9.4 & 7.1 & \multirow{10}{*}{$\mathrm{p}<0.01$} & 7.6 & 6.7 & 8.4 & 10.1 & 0.0 & 0.0 & \\
\hline 乳類·乳製品 & 21.6 & 22.3 & 21.5 & 22.9 & 18.9 & 7.1 & & 24.7 & 26.0 & 23.8 & 20.9 & 36.4 & 0.0 & \\
\hline 大豆·大豆製品 & 5.5 & 6.9 & 4.8 & 5.0 & 3.8 & 0.0 & & 8.6 & 10.2 & 6.1 & 8.8 & 0.0 & 0.0 & \\
\hline 緑黄色野菜 & 12.0 & 14.6 & 11.5 & 9.3 & 11.3 & 0.0 & & 17.5 & 18.8 & 16.8 & 15.5 & 0.0 & 0.0 & \\
\hline 淡色野菜 & 17.2 & 16.4 & 18.5 & 17.9 & 13.2 & 14.3 & & 13.9 & 13.7 & 13.3 & 15.5 & 18.2 & 0.0 & \\
\hline 果実類 & 13.8 & 14.2 & 14.8 & 11.4 & 13.2 & 14.3 & & 12.3 & 12.0 & 13.3 & 8.8 & 36.4 & 0.0 & \\
\hline 海藻類 & 6.4 & 6.2 & 6.6 & 7.9 & 3.8 & 0.0 & & 7.5 & 6.5 & 8.1 & 10.1 & 9.1 & 0.0 & \\
\hline きのこ類 & 2.5 & 2.6 & 3.3 & 2.1 & 0.0 & 0.0 & & 4.8 & 3.9 & 6.1 & 5.4 & 0.0 & 0.0 & \\
\hline その他の食品群 & 1.6 & 1.8 & 1.5 & 1.4 & 1.9 & 0.0 & & 0.9 & 1.0 & 0.9 & 0.7 & 0.0 & 0.0 & \\
\hline 特になし & 8.5 & 4.0 & 5.6 & 12.1 & 24.5 & 57.1 & & 2.2 & 1.2 & 3.2 & 4.1 & 0.0 & 0.0 & \\
\hline \multicolumn{15}{|c|}{ 食生活の自己評価（点） } \\
\hline $0 \sim 19$ & 21.1 & 17.8 & 16.4 & 23.8 & 42.9 & 33.3 & \multirow{5}{*}{$\mathrm{p}<0.01$} & 11.4 & 11.3 & 8.6 & 15.8 & 40.0 & 0.0 & \multirow{5}{*}{ ns } \\
\hline $20 \sim 39$ & 24.3 & 19.6 & 27.3 & 31.7 & 17.9 & 11.1 & & 17.9 & 11.8 & 21.9 & 29.8 & 40.0 & 0.0 & \\
\hline $40 \sim 59$ & 31.2 & 36.4 & 35.4 & 25.4 & 10.7 & 22.2 & & 42.0 & 41.0 & 48.4 & 33.3 & 20.0 & 0.0 & \\
\hline $60 \sim 79$ & 16.7 & 19.6 & 16.4 & 15.9 & 10.7 & 11.1 & & 26.1 & 31.6 & 21.1 & 19.3 & 0.0 & 0.0 & \\
\hline $80 \sim 100$ & 6.6 & 6.5 & 4.5 & 3.2 & 17.9 & 22.2 & & 2.5 & 4.2 & 0.0 & 1.9 & 0.0 & 0.0 & \\
\hline
\end{tabular}

*料理教室·講習会を含む

度国民栄養調査の「性・年齢別, 適切な食事摂取のため に必要な知識・技術の有無」によると,「知識・技術が 十分ある，まあまあある」との回答者の割合が女子 20 29 歳で約 $44 \%$ で, 同年代の男子の約 $25 \%$ より多く, 逆に 「まったくない」は男子約 $24 \%$, 女子約 $9 \%$ あ゙り，女 子に知識・技術があると答えた割合が多かった16)が，今 回の結果では「食に関する知識」は男女とも同程度であ った．吉池らは食事の自己評価で「問題めり」が若者ほ ぞ多く，「問題あり」では欠食，インスタント食品の拱 取や外食が多く, 食事改善への意欲がある場合には家族 の協力, 健康食品の普及や栄養情報サービスおよび外食 での栄養士による指導等が必要であると報告17)してい る.このことから, 若者ではより健康な食生活のために は「強い意志」の必要性を認識しているが, 実践が困難 であることが示唆された。

「健康」に興味・関心がある者ほど多方面から情報を 得ていた.それらの情報源が主として「テレビ・ラジオ」 が多かったが，これら情報のあるものは特定の食品ある
いは成分と健康に焦点を合わせ，その身体における機能 を強調した内容が多いように思われる。このことはある 特定の食品・成分の作用を強調する一方で, 矛盾する情 報の存在も否定できない. 健康 · 栄養に関する知識の情 報に興味・関心をもたなければ，知識として得ることが できず，したがって情報を活用できないことになるが， 一つの側面のみを捉えた情報に惑わされている場合が多 いのではないかと危惧する．情報氾濫時代といわれる現 在, 多くの情報の中から, 取捨選択して正しい情報を取 り入れる能力が必要であると考えられる.そのためには, 食べものに関心をもち, 理解できる年代に正しい栄養教 育が必要である. 運動習慣がある者はない者よりも栄養 素の充足率が高いこと敔，望ましい生活習慣を実施して いる者は健康度評価が高く, その傾向は身体的健康度で 顕著であること年方が報告されている.

今回の調査結果から, いろいろな情報源から知識を得 て健康の大切さを理解・認識していても, 実践が伴わな い若者が多いことが示唆された. 加齢に伴う生活習慣病 

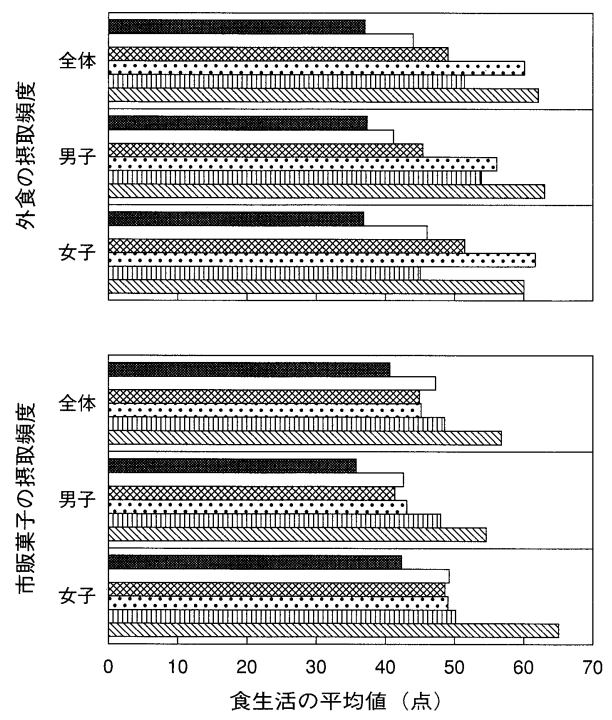

\begin{tabular}{|c|c|c|}
\hline ほに & 1 2/週 & 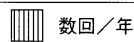 \\
\hline 3 5/週 & 1 2/月 & ほ ほぼなし \\
\hline
\end{tabular}

図 3 食生活の自己評価点の平均値と外食および市販 菓子摂取頻度との関連性

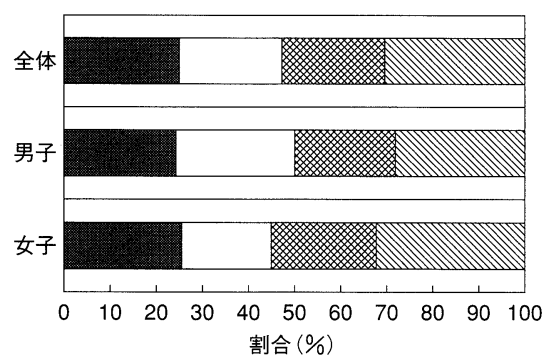

食に関する知識 $\square$ 経済力 時間

図4食生活を充実させるために必要な項目 「食に関する知識」「経済力」「時間」「強い意志」 の 4 項目のうち, 重要だと思う割合を合計 100 \%になるように答えてもらった.

を予防するためにも, 健康・栄養に関する認識や価值観 が確立されつつある青年期に全体的な生活習慣の実態を 理解·認識し, 健康に対して興味・関心をもち, 情報を 正しく判断・選択できる能力を教育の場や講習会で養う とともにこれらを実践する強い意志，実践しやすい環境 やサポートシステムの確立が重要であると考えられる.

\section{4. 要 約}

兵庫, 奈良, 岡山の大学に通う19 24歳の大学生（男 子329名，女子406名）を対象に健康と食生活に関するア ンケート調査を実施した。

1) 調査対象者の多くは健康に興味・関心をもって おり，それらに関する知識の情報源は「テレビ・ラジオ」 が多かった。しかし，健康よりも男子では「遊び」「恋 愛」に，女子では「美容・ファッション」「遊び」に対 する興味・関心の方が強かった。

2 ）健康のために心がけて摂取している食品群は 「乳類 · 乳製品」, 「緑黄色野菜」や「淡色野菜」の野菜 類で, 健康食品は「足りない栄養を補う」ためであった が，利用頻度は低かった。

3 ）健康のために重要視するのは「睡眠時間」,「栄 養バランス」で,「運動」は少なく, また, 女子では 「特に運動をしていない」が約 $43 \%$ 存在した。

4 ）外食の多くは昼食と夕食で, 男子では「洋食定 食」を女子では「洋食一品料理」を選択し, 男女差があ った。

5 ）「健康に興味・関心がある」者ほど日常の食事に 気をつけ，積極的に情報を得て抢り，食生活の自己評価 が高かった．自己評価の高い者ほど外食や市販菓子の摂 取頻度が低かった。

6 ）食生活を充実させるという「強い意志」が食生 活改善に必要であるとの回答が多かったことから, 若者 では健康・栄養に関する知識があり, 健康の大切さを認 識していてもそのための実践が伴わない者が多いことが 示唆された.

\section{文献}

1）厚生省保健医療局健康増進栄養課：栄養学雑誌，51, 171 (1993)

2）吉田博道 : 食生活, 91，14（1997）

3）辰巳真紀, 荒木佐都美, 大野佳美 : 武庫川女子大紀要（自 然科学), 46, 93 (1998)

4）厚生省保健医療局健康増進栄養課監修: 平成 8 年版国民栄 養の現状, 平成 6 年国民栄養調査成績, 第一出版, 東京 (1996)

5）厚生労働省健康局総務課生活習慣病対策室栄養調査係 : 栄 養学䧱誌, 59, 295 (2001)

6）鈴木継美, 和田 攻編 : ミネラル微量栄養素の栄湌学, p.297, 第一出版 (1994)

7) Dawson-Hughes, B.: Am. J. Clin. Nutr., 67, 5 (1998)

8) Greenwald, P., Lanza, E., Eddy, G.A.: J. Am. Diet Assoc., 87, 1178 (1987)

9) Olsen, J., Kronborg, O.: Eur. J. Cancer, 30 (A), 53 (1994)

10) Slattery, M.L., Boucher, K. M., Caan, B. J., Potter, J. D., 
Ma, K. N.: Am. J. Epidemiolo., 148, 4 (1998)

11）厚生省保健医療局地域保健 - 健康増進栄養課生活習慣病対 策室 : 栄養学雑誌, 56, 171 (1998)

12）健康 ·栄養情報研究会編 : 第六次改定日本人の栄養所要 量，食事摂取基準，第一出版（1998）

13）大野佳美, N. C. Lu, 武副礼子, 前田雅子, 平井和子 : 日 本食生活学会誌, 13，212（2002）

14）上野優子, 尾形静香, 川之上豊 : 大妻女子大学家政学系研 究紀要, 37, 101 (2001)

15）彦坂令子, 高橋園美, 矢倉巻和子 : 大妻女子大学家政学系
研究紀要， 36，65（2000）

16）厚生省保健医療局地域保健 ·健康増進栄養課生活習慣病対 策室監修: 国民栄養の現状（平成11年度国民栄養調査結果）， 第一出版, 東京 (2001)

17）吉池信男, 河野美穂, 瀧本秀美, 清野富久江, 多島早奈英, 荒井祐介, 古畑 公: 栄盖学雑誌, 59, 87 (2001)

18）厚生省保健医療局健康増進課：栄湌学雑誌， 55, 137 (1997)

19）徳永幹雄, 橋本公雄：健康科学, 24，39（2002） 